\title{
Dichotomy and dialogue in conceptualizations of competency in health professionals' education
}

\author{
Amelie Blanchet Garneau ,'Patrick Lavoie, Myrian Grondin \\ Université de Montréal, Montréal, Canada
}

Received: November 21, 2016

Accepted: December 20, 2016

Online Published: January 11, 2017

DOI: $10.5430 /$ jnep.v7n6p18

URL: http://dx.doi.org/10.5430/jnep.v7n6p18

\begin{abstract}
Most research on the definition of competency and its application in health professionals' education programs is focused on semantic matters, while contextual influences are rarely discussed or solely presented as background context. The aim of this article is to gain a comprehensive understanding of the issues raised by definitions of competency and to describe the contextual factors that have given rise to those definitions. This is achieved by presenting the results of a literature review that synthesized different conceptualizations of competency. We analyzed relevant literature listed in the CINAHL, Embase, MEDLINE, and PsycINFO databases as of 2015. The results show that authors define competency based on two diverging driving forces: one aimed at professional regulation and the other at professional emancipation. The analysis revealed common grounds between these perspectives. From these common grounds we discuss the possibility of conceptualizing competency on a continuum instead of perpetuating the dichotomized discourses presented in the current literature. The integration of both perspectives gives the opportunity to rethink policies, structures and strategies of professional education toward an integrated perspective of professional development situated in a lifelong learning enterprise, achieving both minimal professional standards and excellence in healthcare practices from initial education throughout a career.
\end{abstract}

Key Words: Competency, Competence, Professional development, Lifelong learning, Health professionals' education

\section{INTRODUCTION}

The competency-based approach shifted the focus from the process to the outcome of education: competencies of learners. ${ }^{[1]}$ In this approach, it is insufficient for learners to follow a curriculum defined by the amount of time spent exposed to what must be learned. Learners must also demonstrate that they are able to use what they have learned. To make this visible, the competency-based approach places greater emphasis on the assessment of education outcomes. In the context of nursing and health professionals' education, the overall aim is to ensure that they are sufficiently equipped to deal with the complexity and evolution of healthcare systems. ${ }^{[2-6]}$

The concept of competency is at the core of the competency- based approach in health professionals' education. Since the 1960s, authors have attempted to define competency from different perspectives (for example, see Gonczi ${ }^{[7]}$ ) but issues of conceptual clarity persist. One can observe the variable use, if not the interchangeability, of the words "competence" and "competency". Most define "competence" as the aspect of a job that an individual is able to perform, and "competency" as the behavior underpinning such performance. ${ }^{[8,9]}$ Others suggest that "competence" would be the potential to perform, whereas "competency" would be the actual performance in accordance with established policies in a specific situation. ${ }^{[10]}$ Another conceptual issue resides in the persisting confusion between "competence" and "performance". According to some, competence is a minimum observable

*Correspondence: Amelie Blanchet Garneau; Email: amelie.blanchet.garneau@ umontreal.ca; Address: Université de Montréal, C.P. 6128, succ. Centre-Ville Montréal, QC, H3C 3J7, Canada. 
performance. ${ }^{[11,12]}$ For others, performance is opposed to competence, with the former representing what a person is able to do when exposed to the actual conditions of a job and the latter as a potential capability in an ideal context. ${ }^{[13]}$

This work appears conflicting and contextual issues surrounding the definitions of competency are barely discussed or solely presented as background information. Therefore, we undertook a literature review to address two main goals: the first was to gain an understanding of the issues raised by the different definitions of competency; the second was to describe the contextual factors that have driven those definitions.

\section{METHODS}

\subsection{Data selection}

A librarian developed a search strategy with combinations of keywords: "competenc*", "education OR supervision OR training", and/or "concept"” and MeSHs. She searched four health-related databases (CINAHL, Embase, MEDLINE, and PsycINFO) with no limits set on date of publication (up to 2015). The first searches yielded a volume of references so large that it would have proved difficult to manage. Accordingly, searches were restricted to reviews, systematic reviews, and meta-synthesis. These forms of research aim to synthesize findings from previous studies through explicit methodologies for the selection and analysis of papers. Therefore, they had the potential to present a comprehensive and integrated view of the concept of interest in a more manageable volume of literature. Papers from health-related disciplines were included. We independently reviewed the titles and abstracts of 603 citations and retrieved full-texts only if the citation announced a definition of competence or competency. We decided to include both competence and competency in our search and analysis because of authors' tendency to use them interchangeably. Papers written in English or French and presenting a methodology for data selection and analysis were included. The first sample comprised 12 papers.

To enhance the credibility and trustworthiness of the results, we explored citations from those papers $(\mathrm{n}=726$; 658 without duplicates). Citations that were referenced in at least two papers from the first sample were considered for a second sample. Those with titles containing "review", "defin*", "concept*" or "synthes*" were also taken into consideration. Inclusion was based on the presence of additional or complementary definitions of competence or competency. The second sample comprised nine papers, making a grand total of 21 papers.

\subsection{Data extraction and analysis}

We extracted data using a grid inspired by Paterson's et al. ${ }^{[14]}$ Primary Research Appraisal Tool and comprising informaPublished by Sciedu Press tion related to the context, methods (when available), and results of the selected papers. Our analysis was informed by interpretive description. ${ }^{[15,16]}$ By identifying common and specific themes across the papers, we built a description of the concept of competency, which took into account the different perspectives encountered. While developing this description, we attempted to identify contextual factors that could explain its different characteristics and patterns.

Once an initial description of the concept of competency was developed, we returned to the original texts in order to test and refine it. When the description was perceived as a plausible account of the diverse perspectives reviewed in the first sample, papers from the second sample were included in the analysis. This was designed to challenge and improve the first tentative interpretation and understanding of the concept of competency.

The description presented herein highlights some of the commonalities and divergences present in the definitions of competency that we reviewed. The constant back-andforth movements from the source papers to the description lends credibility to this work and ensures that it is grounded in the data used for its construction.

\section{RESUlts}

The 21 papers reviewed are summarized in Table 1.

We found two diverging perspectives on competency: one aiming at professional regulation and the other aiming at professional emancipation. Most of the time, these two perspectives were presented discordantly: one with an interest in patient safety and effectiveness of care and the other with an interest in professional development. These two perspectives imply different accounts of the conceptualization and operationalization of competency.

\subsection{Competency for professional regulation}

One perspective on competency sets the regulation of health professionals' practices as its goal. A driving force behind this perspective is the link between health professionals' education and patient safety. In 2003, a report by the Institute of Medicine exposed evidence that new graduates were not prepared to care for patients with comorbidities and complex treatment regimens. ${ }^{[17]}$ Flaws in continuity of care as well as in interdisciplinary collaboration were observed and attributed to gaps in health professionals' qualifications. ${ }^{[18]}$ Medical errors were assumed the result of incompetent practices, whereas patient safety was seen as a result of competent practices. ${ }^{[8,19]}$ The importance of competency in the provision of safe care and its dependence on education appear to have propelled the integration of the competency concept in health professionals' education. 
Table 1. Summary of papers reviewed

\begin{tabular}{|c|c|c|c|c|c|}
\hline $\begin{array}{l}\text { Authors, date, } \\
\text { country }\end{array}$ & $\begin{array}{l}\text { Concept(s) under } \\
\text { study }\end{array}$ & Key aim(s) and objectives & Design & Data sources & Key result(s) or recommendation(s) \\
\hline \multicolumn{6}{|c|}{ First sample } \\
\hline $\begin{array}{l}\text { Aäri, Tarja, \& } \\
\text { Helena, 2008, } \\
\text { Finland }{ }^{[30]}\end{array}$ & $\begin{array}{l}\text { Competence in } \\
\text { adult intensive } \\
\text { care nursing }\end{array}$ & $\begin{array}{l}\text { To define and describe competence, via an } \\
\text { examination of clinical and professional } \\
\text { competence, in adult intensive care nursing } \\
\text { in the light of previous empirical research. }\end{array}$ & $\begin{array}{l}\text { Literature } \\
\text { review with } \\
\text { inductive } \\
\text { content analysis }\end{array}$ & $\begin{array}{l}45 \text { papers } \\
(1994-2005)\end{array}$ & $\begin{array}{l}\text { Four domains of clinical and professional competence: } \\
\text { knowledge, skill, attitude and value, experience. (p. 83) }\end{array}$ \\
\hline $\begin{array}{l}\text { Axley, 2008, } \\
\text { USA }^{[19]}\end{array}$ & Competency & $\begin{array}{l}\text { To explore the uses of the concept } \\
\text { "competency" and theoretically define how } \\
\text { important the multidimensional aspects of } \\
\text { competency are to the professional practice } \\
\text { of nursing. }\end{array}$ & $\begin{array}{l}\text { Walker and } \\
\text { Avant's method } \\
\text { of concept } \\
\text { analysis }^{[31]}\end{array}$ & $\begin{array}{l}\text { Unknown number of } \\
\text { papers, unknown } \\
\text { years covered. } \\
\text { Literature from law, } \\
\text { business, education } \\
\text { and health care }\end{array}$ & $\begin{array}{l}\text { Defining attributes of competency are knowledge, } \\
\text { actions, professional standards, internal regulation and } \\
\text { dynamic state. (p. 218) }\end{array}$ \\
\hline $\begin{array}{l}\text { Carraccio, } \\
\text { Wolfsthal, } \\
\text { Englander, } \\
\text { Ferentz, \& } \\
\text { Martin, 2002, } \\
\text { USA }^{[32]}\end{array}$ & $\begin{array}{l}\text { Competence and } \\
\text { competency }\end{array}$ & $\begin{array}{l}\text { To understand the evolution of the } \\
\text { competency-based education paradigm in } \\
\text { medicine, assess the evidence of its efficacy, } \\
\text { and provide insight for the implementation } \\
\text { and the evaluation of the paradigm shift. }\end{array}$ & $\begin{array}{l}\text { Literature } \\
\text { review, analytic } \\
\text { strategy not } \\
\text { described }\end{array}$ & $\begin{array}{l}68 \text { papers } \\
(1966-2002)\end{array}$ & $\begin{array}{l}\text { Competency is defined as a complex set of behaviors } \\
\text { built on the components of knowledge, skills, and } \\
\text { attitudes. Complex but demonstrable integration of } \\
\text { objectives that are measurable behaviors. Competence is } \\
\text { defined as a personal ability. (p. 362) }\end{array}$ \\
\hline $\begin{array}{l}\text { Castillo, } \\
\text { Caruana, \& } \\
\text { Wainwright, } \\
\text { 2011, Malta }\end{array}$ & Competence & $\begin{array}{l}\text { To review the changes in the definition of the } \\
\text { concept of competence and the } \\
\text { categorisation of learning outcomes in } \\
\text { Europe and their potential impact on the } \\
\text { design of curriculum documents in higher } \\
\text { education (HE) at the European level. }\end{array}$ & $\begin{array}{l}\text { Literature } \\
\text { review, analytic } \\
\text { strategy not } \\
\text { described }\end{array}$ & Not defined & $\begin{array}{l}\text { European curricula should be created or updated to } \\
\text { reflect the categorisation of learning outcomes into } \\
\text { knowledge, skill, and competence proposed in the } \\
\text { European Qualification Framework for lifelong } \\
\text { learning. Competence defined as "the proven ability to } \\
\text { use knowledge, skills and personal, social and/or } \\
\text { methodological abilities, in work or study situations and } \\
\text { in professional and personal development." (p. 233) }\end{array}$ \\
\hline $\begin{array}{l}\text { Charette, } \\
\text { Goudreau, \& } \\
\text { Alderson, 2014, } \\
\text { Canada }^{[18]}\end{array}$ & $\begin{array}{l}\text { Compétence } \\
\text { (French) }\end{array}$ & $\begin{array}{l}\text { To clarify the meaning of the concept of } \\
\text { competence from its recent use in nursing } \\
\text { education. }\end{array}$ & $\begin{array}{l}\text { Rodger's } \\
\text { method of } \\
\text { concept } \\
\text { analysis }^{[33]}\end{array}$ & $\begin{array}{l}41 \text { papers } \\
(2008-2013)\end{array}$ & $\begin{array}{l}\text { Proposed definition of competence: formal action of } \\
\text { systemic skills, contextualized and which is } \\
\text { continuously developing. (p. 28) }\end{array}$ \\
\hline $\begin{array}{l}\text { Cowan, } \\
\text { Norman, \& } \\
\text { Coopamah, } \\
\text { 2005, UK }{ }^{[22]}\end{array}$ & $\begin{array}{l}\text { Competence in } \\
\text { nursing practice }\end{array}$ & $\begin{array}{l}\text { To synthesise and discuss a significant } \\
\text { volume of literature relating to the definition } \\
\text { and subsequent utilisation of the concept of } \\
\text { competence with regard to nursing practice. }\end{array}$ & $\begin{array}{l}\text { Focused review } \\
\text { of the literature }\end{array}$ & $\begin{array}{l}\text { Unknown number of } \\
\text { papers (1995-2003) }\end{array}$ & $\begin{array}{l}\text { Holistic conception of competence appears to have been } \\
\text { largely overlooked: the dichotomy between nursing } \\
\text { competence perceived as either a behavioural objective } \\
\text { or a psychological construct is redundant and a } \\
\text { definition drawing on the holistic conception of } \\
\text { competence should be agreed upon and utilised. (p. 361) }\end{array}$ \\
\hline $\begin{array}{l}\text { Epstein \& } \\
\text { Hundert, 2002, } \\
\text { USA }^{[34]}\end{array}$ & $\begin{array}{l}\text { Professional } \\
\text { competence }\end{array}$ & $\begin{array}{l}\text { To critique current methods of assessing } \\
\text { Accreditation Council for Graduate Medical } \\
\text { Education areas of competence and propose } \\
\text { new means for assessing residents and } \\
\text { medical students. }\end{array}$ & $\begin{array}{l}\text { Literature } \\
\text { review, analytic } \\
\text { strategy not } \\
\text { described }\end{array}$ & $\begin{array}{l}124 \text { papers } \\
(1966-2001)\end{array}$ & $\begin{array}{l}\text { Professional competence: the habitual and judicious use } \\
\text { of communication, knowledge, technical skills, clinical } \\
\text { reasoning, emotions, values, and reflection in daily } \\
\text { practice for the benefit of the individual and community } \\
\text { being served (p. 226). The review focuses on assessment } \\
\text { methods. }\end{array}$ \\
\hline $\begin{array}{l}\text { Fernandez et al., } \\
\text { 2012, Canada } \\
\text { and Belgium }{ }^{[21]}\end{array}$ & Competence & $\begin{array}{l}\text { To illustrate the varying conceptions of } \\
\text { 'competence' by comparing and contrasting } \\
\text { definitions provided in the health sciences } \\
\text { education literature and discussing their } \\
\text { respective impacts on medical education. }\end{array}$ & $\begin{array}{l}\text { Systematic } \\
\text { review of the } \\
\text { literature with } \\
\text { thematic } \\
\text { analysis }\end{array}$ & $\begin{array}{l}14 \text { papers } \\
(1948-2011)\end{array}$ & $\begin{array}{l}\text { Competence: (i) is composed of knowledge, skills and a } \\
\text { series of components related to personal abilities and } \\
\text { attributes; (ii) allows the professional to select or } \\
\text { combine components in order to maintain standards of } \\
\text { performance, and (iii) constitutes a guarantee for the } \\
\text { community or society that the possessor will be able to } \\
\text { perform to acceptable standards (p. 361) }\end{array}$ \\
\hline $\begin{array}{l}\text { Frank et al., } \\
\text { 2010, Canada }\end{array}$ & $\begin{array}{l}\text { Competency-based } \\
\text { education }\end{array}$ & $\begin{array}{l}\text { To review the literature on } \\
\text { competency-based education to identify key } \\
\text { terms and constructs for the development of } \\
\text { a working definition for medical education. }\end{array}$ & $\begin{array}{l}\text { Systematic } \\
\text { review with } \\
\text { qualitative } \\
\text { approach to } \\
\text { identify themes } \\
\text { and } \\
\text { categorizations }\end{array}$ & $\begin{array}{l}173 \text { papers, } \\
(1950-2009)\end{array}$ & $\begin{array}{l}\text { Competency-based education is an approach to } \\
\text { preparing physicians for practice that is fundamentally } \\
\text { oriented to graduate outcome abilities and organized } \\
\text { around competencies derived from an analysis of } \\
\text { societal and patient needs. (p. 636) }\end{array}$ \\
\hline $\begin{array}{l}\text { McMullan, } \\
\text { 2005, UK }{ }^{[25]}\end{array}$ & Competence & $\begin{array}{l}\text { To review the extensive educational and } \\
\text { healthcare literature that exists on the topic } \\
\text { of competence and its assessment. }\end{array}$ & $\begin{array}{l}\text { Literature } \\
\text { review, analytic } \\
\text { strategy not } \\
\text { described }\end{array}$ & $\begin{array}{l}\text { Unknown number of } \\
\text { papers (1989-2004) }\end{array}$ & $\begin{array}{l}\text { Three approaches to competence: behavioural } \\
\text { (performance), generic, and holistic. The most } \\
\text { comprehensive is the holistic approach because it } \\
\text { integrates the two others and places emphasis on the } \\
\text { context and the students' underlying attributes. (p. 49) }\end{array}$ \\
\hline $\begin{array}{l}\text { Morcke, } \\
\text { Dornan, \& Eika, } \\
\text { 2013, Denmark, } \\
\text { Netherlands }^{[8]}\end{array}$ & $\begin{array}{l}\text { Outcome- and } \\
\text { competency-based } \\
\text { education }\end{array}$ & $\begin{array}{l}\text { To review the historical landmarks in the } \\
\text { evolution of outcome-based education, the } \\
\text { conceptual frameworks and theories, and the } \\
\text { empirical publications reporting data } \\
\text { concerning the effects of learning outcomes } \\
\text { on undergraduate medical education. }\end{array}$ & $\begin{array}{l}\text { Literature } \\
\text { review, analytic } \\
\text { strategy not } \\
\text { described }\end{array}$ & 8 papers (1999-2010) & $\begin{array}{l}\text { Outcome-based education and competency-based } \\
\text { education similar with a subtle difference: outcome } \\
\text { defines what skills and qualities we want students to } \\
\text { have, a competency is a determination of what skills and } \\
\text { qualities doctors need to have to care for patients. Both } \\
\text { share a main focus on the product, as opposed to the } \\
\text { process, of curricula. (p. 856) }\end{array}$ \\
\hline $\begin{array}{l}\text { Scott Tilley, } \\
\text { 2008, USA }{ }^{[9]}\end{array}$ & Competency & $\begin{array}{l}\text { To provide a framework for tracking } \\
\text { knowledge, skills, and attitudes throughout a } \\
\text { career in nursing. }\end{array}$ & $\begin{array}{l}\text { Walker and } \\
\text { Avant's method } \\
\text { of concept } \\
\text { analysis }^{[35]}\end{array}$ & $\begin{array}{l}\text { Unknown number of } \\
\text { papers (2000-2006) }\end{array}$ & $\begin{array}{l}\text { Defining attributes of competency: (i) application of } \\
\text { knowledge, interpersonal, decision-making, and psy- } \\
\text { chomotor skills expected for the practice role, (ii) instru- } \\
\text { ction and assessment that places primary emphasis on } \\
\text { specific learning outcomes or competencies, (iii) allo- } \\
\text { wance for increasing levels of competency for } \\
\text { increasingly complex care, (iv) criteria driven, focused } \\
\text { on accountability in reaching benchmarks and, } \\
\text { ultimately, competence, (v) grounded in "real-life" } \\
\text { experiences, (vi) focused on fostering learners' ability to } \\
\text { self-assess, (vii) individualized and providing more } \\
\text { opportunities for independent study (p. 62) }\end{array}$ \\
\hline
\end{tabular}


Table 1. (continued)

\begin{tabular}{|c|c|c|c|c|c|}
\hline $\begin{array}{l}\text { Authors, date, } \\
\text { country }\end{array}$ & $\begin{array}{l}\text { Concept(s) } \\
\text { under study }\end{array}$ & Key aim(s) and objectives & Design & Data sources & Key result(s) or recommendation(s) \\
\hline \multicolumn{6}{|c|}{ Second sample } \\
\hline $\begin{array}{l}\text { Albanese, } \\
\text { Mejicano, } \\
\text { Mullan, } \\
\text { Kokotailo, \& } \\
\text { Gruppen, 2008, } \\
\text { USA }^{[23]}\end{array}$ & Competency & $\begin{array}{l}\text { To identify the characteristics } \\
\text { that define a competency and } \\
\text { proposes criteria that can be } \\
\text { applied to distinguish between } \\
\text { competencies, goals, } \\
\text { objectives and outcomes. }\end{array}$ & $\begin{array}{l}\text { Presents a history of competencies } \\
\text { and a comparison of competencies } \\
\text { identified by international medical } \\
\text { organisations. Develops } \\
\text { distinguishing criteria. }\end{array}$ & Not applicable & $\begin{array}{l}\text { Five characteristics of competency: (i) focuses on the } \\
\text { performance of the end-product of instruction, (ii) reflects } \\
\text { expectations that are an application of what is learned in } \\
\text { the immediate instructional programme, (iii) expressible } \\
\text { in terms of measurable behaviours, (iv) uses a standard for } \\
\text { judging competence that is not dependent upon the } \\
\text { performance of other learners, (v) informs learners (and } \\
\text { other stakeholders) of what is expected of them. (p. 251) }\end{array}$ \\
\hline $\begin{array}{l}\text { Bhatti \& } \\
\text { Cummings, } \\
\text { 2007, USA }\end{array}$ & Competency & $\begin{array}{l}\text { To present a viewpoint that } \\
\text { defines surgical competency, } \\
\text { the measures used to assess } \\
\text { and quantify that competency, } \\
\text { and the criteria used to judge } \\
\text { whether it has been achieved } \\
\text { are critical issues }\end{array}$ & $\begin{array}{l}\text { Presents and discusses different } \\
\text { definitions of competency and } \\
\text { approaches to its assessment. }\end{array}$ & Not applicable & $\begin{array}{l}\text { In surgery, competence is the ability to successfully apply } \\
\text { professional knowledge, skills, and attitudes to new } \\
\text { situations as well as to familiar tasks (p. 569). Competence } \\
\text { can be defined as the aspect of a job that an individual is } \\
\text { able to perform, whereas competency is the behavior } \\
\text { underpinning such performance (p. 570). }\end{array}$ \\
\hline $\begin{array}{l}\text { Clements \& } \\
\text { Mackenzie, } \\
\text { 2005, UK }{ }^{[36]}\end{array}$ & Competence & $\begin{array}{l}\text { To explore the concepts of } \\
\text { competence, define the } \\
\text { terminology, and describe the } \\
\text { role of a competence } \\
\text { framework in education and } \\
\text { training. }\end{array}$ & $\begin{array}{l}\text { Presents and discusses definitions of } \\
\text { competence and the Competency } \\
\text { Framework for Emergency Care } \\
\text { (UK). }\end{array}$ & Not applicable & $\begin{array}{l}\text { Competence is fundamentally related to occupational roles } \\
\text { and the operational level of expertise expected of the } \\
\text { individual practitioner. Achievement of competence } \\
\text { requires demonstration of a defined range of underpinning } \\
\text { knowledge, psychomotor skills, and behavioural } \\
\text { attributes. (p. 516) }\end{array}$ \\
\hline $\begin{array}{l}\text { Eraut, 1998, } \\
\text { UK }^{[12]}\end{array}$ & Competence & $\begin{array}{l}\text { To deconstruct the concept of } \\
\text { competence by reviewing the } \\
\text { range of meanings which have } \\
\text { been ascribed to it and the } \\
\text { circumstances which gave rise } \\
\text { to these meanings. }\end{array}$ & $\begin{array}{l}\text { Analysis of everyday use of the term } \\
\text { and literature review. }\end{array}$ & Not applicable & $\begin{array}{l}\text { The general public has a socially situated definition of } \\
\text { competence (close to that of performance). Competence is } \\
\text { the ability to perform the tasks and roles required to the } \\
\text { expected standard, in reference to a particular job. } \\
\text { Professional capability is defined as what a person can } \\
\text { think or do that is relevant to the work of a particular } \\
\text { profession. (p. 135) }\end{array}$ \\
\hline $\begin{array}{l}\text { Garside \& } \\
\text { Nhemachena, } \\
\text { 2013, UK }{ }^{[26]}\end{array}$ & Competence & $\begin{array}{l}\text { To explore various facets of } \\
\text { competence, particularly how } \\
\text { it has been interpreted, applied } \\
\text { and transformed over the years } \\
\text { within nurse education in the } \\
\text { UK. }\end{array}$ & $\begin{array}{l}\text { Walker and Avant's method of } \\
\text { concept analysis }{ }^{[35,37]} \text {. }\end{array}$ & $\begin{array}{l}\text { Unknown } \\
\text { number of } \\
\text { papers, } \\
\text { unknown years } \\
\text { covered. } \\
\text { Presents } \\
\text { literature from } \\
1984 \text { to } 2010 .\end{array}$ & $\begin{array}{l}\text { The analysis identified how influential academics and } \\
\text { professional bodies have attempted to provide definitions } \\
\text { and concluded that it may be the existence of so many of } \\
\text { these definitions, which has compounded the conundrum } \\
\text { of what competence really is (p. 541). Multiple } \\
\text { conceptions are presented. }\end{array}$ \\
\hline $\begin{array}{l}\text { Milligan, } \\
1998^{[24]}\end{array}$ & Competence & $\begin{array}{l}\text { To clarify the concept of } \\
\text { competence, its relevance or } \\
\text { otherwise, and explore the lack } \\
\text { of debate with regard to the } \\
\text { manner in which so-called } \\
\text { competence is achieved. }\end{array}$ & $\begin{array}{l}\text { Presents and discusses definitions of } \\
\text { competence and their } \\
\text { operationalization for assessment in } \\
\text { the context of education and training. }\end{array}$ & Not applicable & $\begin{array}{l}\text { It is suggested that a holistic conceptualization of } \\
\text { competence is the most appropriate for nurse/midwifery } \\
\text { education: one that empowers students and practitioners, } \\
\text { facilitating critical thinking, rather than emphasizing } \\
\text { outcomes over the importance of educational process and } \\
\text { the use of a variety of forms of knowledge in practice. (p. } \\
\text { 273) }\end{array}$ \\
\hline $\begin{array}{l}\text { Norman, } \\
1985^{[13]}\end{array}$ & $\begin{array}{l}\text { Clinical } \\
\text { competence }\end{array}$ & $\begin{array}{l}\text { To review the various methods } \\
\text { used to define competence and } \\
\text { point out the strengths and } \\
\text { limitations of each. }\end{array}$ & $\begin{array}{l}\text { Presents and critiques a variety of } \\
\text { approaches to define competence: } \\
\text { (i) reflective or philosophical, } \\
\text { (ii) task analysis, (iii) descriptive } \\
\text { studies, (iv) studies of diagnostic } \\
\text { thinking, (v) consumer opinion, } \\
\text { (vi) epidemiologic and quality of } \\
\text { care. }\end{array}$ & Not applicable & $\begin{array}{l}\text { No single method can adequately define the prerequisite } \\
\text { knowledge, skills, and attitudes required of a competent } \\
\text { physician in a particular specialty. Each method has } \\
\text { certain limitations, whether from the biases inherent in the } \\
\text { method or its limited focus (p.31). However, the } \\
\text { specification of the components is usually arranged into } \\
\text { domains of competence such as knowledge, technical } \\
\text { skills, or interpersonal skills (p.32). }\end{array}$ \\
\hline While, $1994^{[38]}$ & $\begin{array}{l}\text { Competence } \\
\text { and } \\
\text { performance }\end{array}$ & $\begin{array}{l}\text { To review the literature in the } \\
\text { field of competence and } \\
\text { performance. }\end{array}$ & $\begin{array}{l}\text { Presents and discusses conceptions } \\
\text { of both concepts in light of } \\
\text { assessment. }\end{array}$ & $\begin{array}{l}\text { Relies on the } \\
\text { literature review } \\
\text { for another } \\
\text { research project. }\end{array}$ & $\begin{array}{l}\text { Much confusion between the constructs of competence } \\
\text { and performance. Since nurse pre-registration education } \\
\text { is concerned with producing nurses who consistently } \\
\text { provide care of a high quality, greater emphasis should be } \\
\text { placed upon performance m the real-life clinical setting } \\
\text { rather than upon competence. }\end{array}$ \\
\hline $\begin{array}{l}\text { Yip \& Smales, } \\
2000^{[39]}\end{array}$ & Competency & Not defined & $\begin{array}{l}\text { Discusses the concept of } \\
\text { competency. Discusses the } \\
\text { competency-based education in } \\
\text { dentistry and evaluation in this } \\
\text { context. }\end{array}$ & Not applicable & $\begin{array}{l}\text { New graduates are competent when they are capable of } \\
\text { functioning (independently) in realistic practice settings. } \\
\text { Competencies combine the attributes of appropriate } \\
\text { supporting knowledge and professional attitudes, and } \\
\text { reliable performance undertaken in natural settings } \\
\text { without assistance. (p. 324) }\end{array}$ \\
\hline
\end{tabular}

Another driving force behind the regulatory perspective is healthcare systems reliance on public funding. Bhatti and Cummings ${ }^{[20]}$ stated that the "societal expectation that surgeons/physicians will be competent is embedded in the premise that they are fiduciary professionals" (p. 569). Health professionals' services should benefit the individual and community being served. ${ }^{[1,12]}$ Hence, health professionals must act efficiently and effectively to prevent unnecessary expenses while remaining aligned with the society's and their patients' needs. ${ }^{[21]}$ There is therefore a financial im- perative behind the requirement of competency for health professionals' practice.

Altogether, these driving forces posit competency as a requirement for patient safety, but also as an imperative from health professionals' remuneration with public funding. In this perspective, authors defined competency as the ability to practice safely and effectively without supervision. ${ }^{[22]}$ Accordingly, being competent becomes a guarantee that the professional will be able to perform to society's expecta- 
tions $^{[12,22]}$ and deliver safe and efficient healthcare services.

This conceptualization of competency supports the definition of professional standards as minimum criteria to be eligible to earn a professional title after proper training. To call himself a professional, one is expected to perform up to those job-specific standards, which represent a description of practice (action and behaviors) in a domain. ${ }^{[12,22]}$ These standards divide competency into discrete components that are observable and measurable in practice. Accordingly, assessment of practice is centered on students' and professionals' behaviors and performance when conducting tasks required in the course of a working role in an institution. The attainment and maintenance of professional standards is to be achieved through initial and continuing education. As such, competency is an outcome of training. Hence, students or professionals lacking ability in specific tasks could be asked to undergo training or to leave the profession. It is the individual's responsibility to maintain competency when performing certain tasks.

\subsection{Competency for professional emancipation}

Another perspective on competency relates to professionals' emancipation. Empowerment of professionals and their full engagement in professional development toward excellence in practice is at the core of this perspective. This perspective rose from the critics of standards of practice as being taskcentered, thus obscuring the knowledge that underlies the performance. ${ }^{[2]}$ Hence, an orientation towards excellence in professional practice through engagement in professional development is a main driving force.

Following this emancipatory perspective, competency is not only what a professional needs to be able to do, but also what he or she could do. ${ }^{[8,23]}$ Competency is more than a personal capability, but also represents a potential for action. Milligan $^{[24]}$ advocates for a definition of competency that "empowers students and practitioners, facilitating critical thinking, rather than emphasizing (...) outcomes over the importance of educational process and the use of a variety of forms of knowledge in practice" (p. 273). Hence, the focus is more on complex requirements of professional practice, such as problem resolution and complex situation management, than on specific observable behaviors.

Some authors from this perspective considered competency to be systemic and holistic. ${ }^{[1,25]}$ They suggest that competency is not an end in itself, but constitutes a process of lifelong learning reinforced through continuing education during a health professional's career. ${ }^{[26]}$ Initial education cannot ensure the acquisition of sufficient knowledge and skills for a lifetime of practice. Consequently, there is a formal level of knowledge required for entry into practice, but competency is to be developed through experience and continuing education.

In this perspective, operationalizing professional competency becomes a challenge. With experience, the professional's practice becomes reflective, thus implying tacit knowledge and unusual combinations of resources. The practice then becomes greater than the sum of its parts, which makes it difficult to divide into discrete and measurable components. Moreover, assessment becomes even more complex considering that competency is bound to social, economic, and political contexts of healthcare practice. Thus, any effort to find a universal definition of competency will inevitably fail. ${ }^{[23]}$

\subsection{Common grounds of regulatory and emancipatory perspectives}

There were common grounds between the regulatory and emancipatory perspectives on competency. From both perspectives, competency is deployed into action and implies the application of knowledge to real-life situations. ${ }^{[12,22]}$ Competency is considered to be dynamic, context-dependent, and to evolve with time. ${ }^{[1]}$ Effectiveness of care is also a shared goal. Both perspectives highlight that competency is an aptitude to consistently and repeatedly perform tasks effectively. ${ }^{[12]}$ Moreover, being competent requires the ability to manage ambiguity, uncertainty, and complex situations, acquiring and using knowledge to solve real-life problems, using biomedical and psychosocial data in clinical reasoning. ${ }^{[1,12,22]}$ Therefore, according to both perspectives, a competent health professional shall perform tasks and roles with desirable outcomes in a variety of circumstances in the real world. Figure 1 presents a summary of the results for both perspectives, including common characteristics at the center of the figure.

\section{Discussion}

We presented two perspectives of competency found in the current literature: one aiming at professional regulation and the other aiming at professional emancipation. They diverge on some points. The regulatory perspective regards competency as a finite outcome of education, whereas the emancipatory perspective leans towards competency as a lifelong learning process. For one, competency represents a minimal level of expected standards; for the other it represents excellence in practice.

Nonetheless, results also highlight common grounds between both perspectives, which suggest that they share some characteristics. Therefore, we believe it is important to revisit those diverging perspectives through a lens of integration, 
rather than opposition. The focus of this discussion is on the diverging characteristics of both perspectives of competency and how we could envision them as dialogical components of that concept. While rethinking the dichotomies found in the literature on definitions of competency, we thus discuss three dialectics present in the conceptualizations of competency and the possibility to envision these dialectics through a continuum in the service of patient safety and excellence in healthcare practices.

\subsection{Competency as an outcome and a process}

To oppose outcome and process in the conceptualization of competency seems to create a gap between initial and continuing education. On one hand, regulatory discourses centered on professional accountability and patients' safety are fo- cused on competency as an outcome of initial education and qualification. On the other hand, emancipatory discourses centered on professionals' empowerment and excellence in care describe competency as a lifelong learning process. ${ }^{[8,26]}$ We acknowledge that both patient safety and excellence in care are essential for professional practice. However, we claim that competency is developmental and that it can be conceptualized both as process and an outcome. Competency continues to develop through different stages of education and career and, at each stage, is observable through indicators that operationalize specific outcomes. Hence, this conception offers the possibility to establish a continuum between initial qualifications and continuing education through developmental stages.

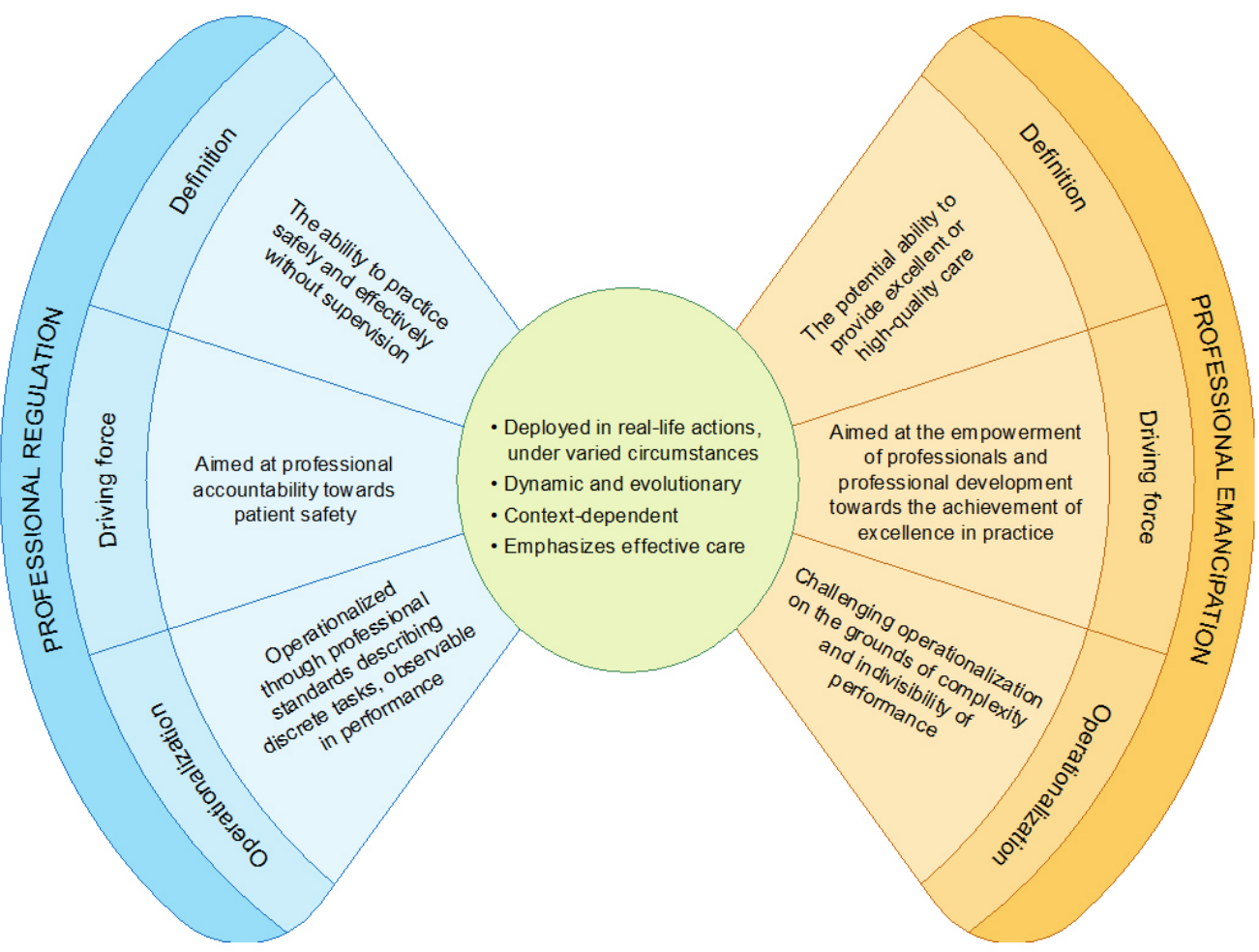

Figure 1. Summary of the results: regulatory and emancipatory perspectives of competency

\subsection{Competency as minimal standards and excellent practice}

The regulatory and emancipatory perspectives oppose minimal standards of performance to excellent practice. According to the regulatory perspective, health professionals are expected to minimally perform their care in order to ensure patient safety and be accountable for their professional practice. Following an emancipatory perspective, the preoccupation with excellence and improvement of practice gave rise to expectations of high-performances from students and health professionals. They are expected and trained to maximally exploit their potential and to contribute to the transformation of current healthcare practices in clinical settings. By integrating both perspectives, competency can comprise both minimal expectations for patient safety and high expectations for excellence of care and improvement of practice. This means that minimal and excellent levels of practice should be taken into consideration when defining the indicators of a developmental stage of competency. Indeed, we want health professionals to excel at different levels of their professional development, but we also want to ensure that patient safety is achieved at each of these levels. 


\subsection{Competency as individually and socially situated}

The dialectic of competency as being both individually and socially situated is present in the two perspectives presented. Indeed, competency implies that an individual combines and mobilizes selected components to effectively deliver care. ${ }^{\text {[24] }}$ However, the selection, combination, and mobilization of components can vary according to contexts of practice, regulations, and health and social structures that define these contexts. Competency is in fact bounded to local social, economic, and political circumstances, as well as health needs of individuals and communities, the availability of resources, and the structure of the healthcare system. ${ }^{[23]} \mathrm{Er}-$ aut ${ }^{[12]}$ suggests that the conception of competency is the result of implicit or explicit negotiations between employers, professionals, clients, professional bodies, academic institutions, and governments. Thus, there can be multiple aims of competency, representing diverse interests depending on the perspective adopted. Competency is defined by a constant interaction between the individual and its context, which makes them inseparable. Individuals are situated in a context that they can influence and also be influenced by. The context can both enable and constrain the selection, combination, and mobilization of components by an individual, which in turn can influence the context. Consequently, this contextual aspect should be taken into account when defining developmental stages of competency and their indicators.

\subsection{Limitations of this study}

This literature review was solely based on other literature reviews. As such, our findings are based on syntheses of the literature that might have been influenced by other authors' views or perspectives. Also, the methodological quality of the previous literature reviews would have been difficult to assess as a result of frequent omission of a description of their methods.

\subsection{Implications for health professionals' education}

The integration of emancipatory and regulatory perspectives of competency highlights the developmental and contextual characteristics of the concept. Moreover, by conceptualizing competency as both process-oriented and outcome-oriented, being competent at different stages of a professional career becomes possible. Hence, competency may not represent a particular level of performance, as in Benner's ${ }^{[27]}$ noviceto-expert model, but could be present at each stage of a professional's career, albeit with differing meanings. The definition of what it means to be competent could also vary accordingly to specific context of practice.

This comprehensive conceptualization of competency emphasizes the continuity between initial and continuing education and advances professional development throughout a person's career. Thus, situating competency development in the context of an integrated perspective of professional development seems more appropriate to ensure both patient safety and excellence in healthcare practices. In order to do that, the literature on lifelong learning is helpful in rethinking structures that are guiding health professionals' education and orienting them towards an integrated perspective of professional development. As Alsop ${ }^{[28]}$ stated,

"although new requirements regarding professional regulation and maintenance of competence have provided the impetus for continuing professional development, a much wider perspective on learning should also be taken. Lifelong learning embraces improvement of knowledge, skill and personal competence in order to participate actively within society across the lifespan and not just in working life" (p. vii).

Lifelong learning is in line with a dialectical conceptualization of competency as it goes beyond the effort to maintain competence to practice in the professional role towards supporting career development and self-fulfilment at any time of life. ${ }^{[28]}$

Promoting a lifelong learning culture among health professionals requires the involvement of multiple actors such as professional regulation bodies, employers, universities, providers of professional education and training, and health professionals themselves. A dialectical conceptualization of competency could help in developing tools for these actors to be involved in respect to their responsibilities towards professional development. For example, managers, educators, and regulation bodies could collaborate in the conception of competencies development frameworks grounded in empirical evidence that identify target competencies to develop in specific clinical contexts and propose multiple stages of development. These frameworks could assist managers in their attempt to promote competency development and lifelong learning among health professionals working in their organizations. They could also serve as a guide for health professionals to identify their learning needs and engage actively in their professional development. The use of professional portfolios showing milestones in health professionals' competencies development is also a helpful tool to display the development of competencies from initial education throughout a career. ${ }^{[29]}$ Professional portfolios could promote the development of new competencies among health professionals and assist them in making decisions about the ways in which they want their career to progress. Health professional would then be actively engaged in their professional development and their learning experience would be more personalised, meaningful, relevant, and pragmatically valuable. ${ }^{[29]}$ 
Finally, researchers could explore how to integrate a lifelong learning perspective through the development of competencies in health professionals' curriculum. Developing and testing pedagogical strategies such as professional portfolios could be part of this research agenda. Competencies development would then help to prepare students and health professionals for the ever evolving context of health care and enhance both their employability and personal growth.

\section{Conclusion}

A dialectical conceptualization of competency gives the opportunity to rethink structures and patterns of professional education toward an integrated perspective of professional development situated in a lifelong learning enterprise, achieving both minimal professional standards and excellence in healthcare practices. Through such an enterprise, it is conceivable that health professionals would be equipped to deal with the complexity and evolution of healthcare systems within their contextual peculiarities, as well as being capable of reconciling their own professional needs and expectations with those of the public. However, it also raises important questions regarding who is responsible and accountable for this professional development and continuing education activities. It reminds us of the importance of partnerships between professional regulation bodies, employers, universities, providers of professional education and training, and health professionals themselves.

\section{ACKNOWLEDGeMENTS}

This work was supported by Équipe FUTUR, which is funded by the Fonds de recherche du Québec - Société et culture (FRQSC).

\section{CONFLicts OF INTEREST Disclosure}

The authors declare that they have no competing interests.

\section{REFERENCES}

[1] Frank JR, Mungroo R, Ahmad Y, et al. Toward a definition of competency-based education in medicine: A systematic review of published definitions. Med Teach. 2010 Jul 27; 32(8): 631637. PMid:20662573 https://doi.org/10.3109/0142159X . 2 010.500898

[2] Benner P, Sutphen M, Leonard V, et al. Educating nurses: A call for radical transformation. San Francisco, CA: Jossey-Bass; 2010. 288 p.

[3] Brownie S, Bahnisch M, Thomas J. Competency-based education and competency-based career frameworks: Informing Australia health workforce development. Adelaide, Australia: University of Queensland Node of the Australia Health Workforce Institute in partnership with Health Workforce Australia; 2011. 102 p.

[4] Frenk J, Chen L, Bhutta ZA, et al. Health professionals for a new century: Transforming education to strengthen health systems in an interdependent world. The Lancet. 2010 Dec 4; 376(9756): 19231958. https ://doi.org/10.1016/S0140-6736(10)61854-5

[5] González J, Wagenaar R. Universities' contribution to the Bologna Process: An introduction. 2nd ed. Spain: Publicationes de la Universidad de Deusto; 2008. 160 p.

[6] Royal college of physicians and surgeons of Canada. Competence by design: Reshaping canadian medical education [Internet]. 2014 Mar [cited 2016 Nov 16]. Available from: http://www.royalcollege.ca/portal/page/portal/rc/ common/documents/educational_initiatives/rc_compet ency-by-design_ebook_e.pdf

[7] Gonczi A. Competency based assessment in the professions in Australia. Assess Educ. 1994; 1(1): 27-44. https ://doi.org/10.108 0/0969594940010103

[8] Morcke AM, Dornan T, Eika B. Outcome (competency) based education: An exploration of its origins, theoretical basis, and empirical evidence. Adv Health Sci Educ. 2013 Oct; 18(4): 851-863. https://doi.org/10.1007/s10459-012-9405-9
[9] Scott Tilley DD. Competency in nursing: A concept analysis. J Contin Educ Nurs. 2008 Feb; 39(2): 58-64; quiz 65-56, 94. http: //dx.doi.org/10.3928/00220124-20080201-12

[10] McConnell EA. Competence vs. competency. Nurs Manage. 2001 May; 32(5): 14. PMid:15103833 https ://doi.org/10.1097/00 006247-200105000-00007

[11] Castillo J, Caruana CJ, Wainwright D. The changing concept of competence and categorisation of learning outcomes in Europe: Implications for the design of higher education radiography curricula at the European level. Radiography. 2011 Aug; 17(3): 230-234. https://doi.org/10.1016/j.radi.2010.12.008

[12] Eraut M. Concepts of competence. J Interprof Care. 1998; 12(2): 127-139. https://doi .org/10.3109/13561829809014100

[13] Norman GR. Defining competence: A methodological review. In: Neufeld VR, Norman GR, eds. Assessing Clinical Competence. New York, NY: Springer; 1985. 366 p.

[14] Paterson BL, Thorne S, Canam C, et al. Meta-study of qualitative health research. Thousand Oaks, CA: Sage; 2001. 176 p. https : //doi.org/10.4135/9781412985017

[15] Thorne S, Reimer Kirkham S, MadDonald-Emes J. Interpretive description: A noncategorical qualitative alternative for developing nursing knowledge. Res Nurs Health. 1997 Apr; 30: 169-177. https : //doi.org/10.1002/(SICI) 1098-240X (1997 04) $20: 2<169:$ : AID-NUR9>3.0.CO;2-I

[16] Thorne S, Reimer Kirkham S, O'Flynn-Magee K. The analytic challenge in interpretive description. Int J Qual Methods. 2004; 3(1): $1-11$.

[17] Institute of Medicine. Health professions education: A bridge to quality. Washington (DC): The National Academic Press; 2003. 192 p.

[18] Charette M, Goudreau J, Alderson M. [An evolutionist analysis of competence]. Rech Soins Infirm. 2014; 116: 28-39. French. https://doi.org/10.3917/rsi.116.0028

[19] Axley L. Competency: A concept analysis. Nurs Forum. 2008 Oct; 43(4): 214-222. PMid:19076465 https ://doi.org/10.1111/j $1744-6198.2008 .00115 . x$ 
[20] Bhatti NI, Cummings CW. Competency in surgical residency training: Defining and raising the bar. Acad Med. 2007 Jun; 82: 569-579. PMid:17525542 https://doi.org/10.1097/ACM. Ob013e3180 $555 \mathrm{bfb}$

[21] Fernandez N, Dory V, Ste-Marie LG, et al. Varying conceptions of competence: An analysis of how health sciences educators define competence. Med Educ. 2012 Mar 16; 46(4): 357-365. PMid:22429171 https://doi.org/10.1111/j.1365-2923.20 11.04183. $\mathrm{x}$

[22] Cowan DT, Norman I, Coopamah VP. Competence in nursing practice: A controversial concept - a focused review of literature. Nurse Educ Today. 2005 Jul; 25(5): 355-362. PMid:15904996 https://doi.org/10.1016/j.nedt.2005.03.002

[23] Albanese MA, Mejicano G, Mullan P, et al. Defining characteristics of educational competencies. Med Educ. 2008 Feb 8; 42(3): 248-255 PMid:18275412 https : //doi.org/10.1111/j.1365-2923. 20 $07.02996 . x$

[24] Milligan F. Defining and assessing competence: The distraction of outcomes and the importance of educational process. Nurse Educ Today. 1998 May; 18(4): 273-280. https ://doi.org/10.1016/ S0260-6917 (98) 80044-0

[25] McMullan J. Competence and its assessment: A review of the literature. Br J Podiatry. 2005 May; 8(2): 49-52.

[26] Garside JR, Nhemachena JZ. A concept analysis of competence and its transition in nursing. Nurse Educ Today. 2013 May; 33(5): 541 545. PMid:22257583 https://doi.org/10.1016/j.nedt. 201 1.12 .007

[27] Benner P. From novice to expert, excellence and power in clinical nursing practice. Menlo Park, CA: Addison-Wesley; 1984. 307 p.

[28] Alsop A. Continuing professional development in health and social care: Strategies for lifelong learning. 2nd ed. West Sussex (UK) Wiley-Blackwell; 2013. 176 p. https ://doi.org/10.1002/9781 118782859
[29] McIlveen P, Brooks S, Lichtenberg A, et al. Career development learning frameworks for work-integrated learning. In Henderson A, Billett S, eds. Developing learning professionals: Integrating experiences in university and practice settings. London, UK: Springer; 2011. 220 p. https : //doi .org/10.1007/978-90-481-3937-8_9

[30] Aäri R, Tarja S, Helena L. Competence in intensive and critical care nursing: A literature review. Intensive Crit Care Nurs. 2008 Apr; 24(2): 78-89. PMid:18206373 https ://doi.org/10.1016/j.ic cn.2007.11.006

[31] Walker LO, Avant KC. Strategies for theory construction in nursing. 3rd ed. Norwalk, CT: Appleton \& Lange; 1995. 222 p.

[32] Carraccio C, Wolfsthal SD, Englander R, et al. Shifting paradigms: From flexner to competencies. Acad Med. 2002 May; 77(5): 361-367. PMid:12010689 https ://doi.org/10.1097/00001888-20020 5000-00003

[33] Rodgers BL, Knafl KA. Concept development in nursing: Foundations, techniques and applications. 2nd ed. Philadelphia, PA: WB Saunders; 2000. 458 p.

[34] Epstein RM, Hundert EM. Defining and assessing professional competence. J Am Med Assoc. 2002 Jan 9; 287(2): 226. PMid:11779266 https://doi.org/10.1001/jama.287.2.226

[35] Walker LO, Avant KC. Strategies for theory construction in nursing. 4th ed. Upper Saddle River, NJ: Pearson/Prentice Hall; 2005. 227 p.

[36] Clements R, Mackenzie R. Competence in prehospital care: Evolving concepts. Emerg Med J. 2005 Jul 1; 22(7): 516-519. PMid:15983094 https://doi.org/10.1136/emj . 2005.026237

[37] Walker LO, Avant KC. Strategies for theory construction in nursing. 2nd ed. Norwalk, CT: Appleton \& Lange; 1988. 227 p.

[38] While AE. Competence versus performance: Which is more important? J Adv Nurs. 1994 Sep; 20(3): 525-531. PMid:7963060 https://doi.org/10.1111/j.1365-2648.1994.tb02391.x

[39] Yip HK, Smales RJ. Review of competency-based education in dentistry. Br Dent J. 2000 Sep 23; 189: 324-326. PMid:11060954 https://doi.org/10.1038/sj.bdj.4800758 